medRxiv preprint doi: https://doi.org/10.1101/2020.12.26.20248872; this version posted January 2, 2021. The copyright holder for this preprint (which was not certified by peer review) is the author/funder, who has granted medRxiv a license to display the preprint in It is made available under a CC-BY-ND 4.0 International license.

\title{
The new Coronavirus (SARS-CoV-2) in Central America: Demographic-spatial simulations, Analyses of Molecular Variance (AMOVA) and Neutrality Tests in complete genomes from Belize, Guatemala, Cuba, Jamaica and Puerto Rico
}

Pierre Teodosio Felix*; Robson da Silva Ramos; Dallynne Bárbara Ramos Venâncio; Eduarda Doralice Alves Braz Da Silva; Rosane Maria de Albuquerque

Laboratory of Population Genetics and Computational Evolutionary Biology -

LaBECom, UNIVISA, Vitória de Santo Antão, Pernambuco, Brazil.

*Corresponding author/ Contact: pierrefelix@univisa.edu.br

Keywords: COVID-19, SARS-CoV-2, Coronavirus, Demographic-spatial simulations; AMOVA, Neutrality Tests, Bioinformatics, Central America

\begin{abstract}
In this work, we evaluated the levels of genetic diversity in 38 complete genomes of SARS-CoV-2 from five Central American countries (Belize, Guatemala, Cuba, Jamaica and Puerto Rico) with 04, 10, 2, 8 and 14 haplotypes, respectively, with an extension of up to $29,885 \mathrm{bp}$. All sequences were publicly available on the National Biotechnology Information Center (NCBI) platform. Using specific methodologies for paired FST, $_{\text {, }}$ AMOVA, mismatch, demographic-spatial expansion, molecular diversity and for the time of evolutionary divergence, it was possible to notice that only 79 sites remained conserved and that the high number of polymorphisms found helped to establish a clear pattern of genetic non-structuring, based on the time of divergence between the groups. The analyses also showed that significant evolutionary divergences within and between the five countries corroborate the fact that possible rapid and silent mutations are responsible for the increase in genetic variability of the Virus, a fact that would hinder the work with molecular targets for vaccines and medications in general.
\end{abstract}

\section{Introduction}

COVID-19 is the acute respiratory infection that has been causing a great impact NOTE: This preprint reports new research.that has not been cerfified by peer review and should not be used to guide clinical practice. and international damage in recent decades and the greatest management strategy has 
medRxiv preprint doi: https://doi.org/10.1101/2020.12.26.20248872; this version posted January 2, 2021. The copyright holder for this preprint (which was not certified by peer review) is the author/funder, who has granted medRxiv a license to display the preprint in perpetuity.
It is made available under a CC-BY-ND 4.0 International license.

been to avoid exposure to the virus. In Latin America, specifically in the Central American sub-region that includes seven independent countries: Guatemala, Belize, Honduras, El Salvador, Nicaragua, Costa Rica and Panama; the impact on the health system and specifically on primary care has been enormous. In Honduras and other Central American countries, the first cases reported were in larger and therefore most populous cities, which were affected in terms of reported cases. In early July 2020, a positivity of $41.1 \%$ was found, being the second highest in the region. (HENRIQUEZMARQUEZ et al, 2020).

Currently in Costa Rica, the lethality rate shows a wide variation of about $0.46 \%$. At first sight, obvious correlations between accumulated incidences and parameters such as those related to climate, geographic characteristics or population peculiarities need to be studied when seroepidemiological surveys are made that allow a better approximation of the actual numbers of infected people. (CALLEJAS et al, 2020).

In mid-March, there was a substantial increase in cases of COVID-19, resulting in almost all countries in Latin America and the Caribbean (LAC). However, many areas throughout LAC, including Central America, have no information or have substantial gaps in information. Epidemiological details are often lacking due to the challenges in case-finding bias and the lack of serological tests. (ANDRUS et al, 2020). Although the implementation of strategies has been applied in most Latin American countries, there are intrinsic characteristics of the local community determined by many factors, such as demographic data, endemic infections and environmental conditions that can influence the outcome of infection in the region (BAUTISTA-MOLANO et al, 2020; YUAN, et al, 2020).

In Central America, Panama is the country most affected by the pandemic, followed by Honduras, Guatemala, El Salvador, Costa Rica and Nicaragua. At the global level, as the transmission of SARS-CoV-2 continues to advance, the main objective of health systems in many Latin American countries, and specifically in Central America, is the adoption of an epidemiological surveillance model adapted to the conditions of each country that reduce infection to a normal curve; The model is mainly based on the identification and screening of infected people, rapid response testing and treatment in critically injured patients, as well as the protection of people at greatest risk and vulnerability. In any case, the goal is to stop the explosive outbreak of the epidemic and accompany it with measures of isolation and confinement that, have been very drastic and severe in some countries and in others, looser and permissive (CALLEJAS et al, 2020). 
medRxiv preprint doi: https://doi.org/10.1101/2020.12.26.20248872; this version posted January 2, 2021. The copyright holder for this preprint (which was not certified by peer review) is the author/funder, who has granted medRxiv a license to display the preprint in It is made available under a CC-BY-ND 4.0 International license .

Strict controls to limit entry and exit into American countries have also been an important impact strategy in containing the spread of COVID-19, as, with a large part of the region economically dependent on international tourism, measures regulating border flow balance competing demands for economic well-being and public health. It is expected that these control measures delay the spread of the virus and reduce the severity of the peak of the epidemic (MURPHY et al. 2020; ESCOBEDO et al, 2020).

While most Central American countries, as well as much of Asia and Africa are still preparing to detect and deal with COVID-19 outbreaks, it is essential to step up the training of the intercontinental and intracontinental health workforce, since in the Latin American region there is a great heterogeneity of political and social development, economic growth and political capacities (RODRIGUEZ-MORALES et al, 2020).

Currently, even with the onset of vaccines, we cannot deny that in Latin America there are deficiencies in its health systems and infrastructure, especially a deficit of intensive care beds and mechanical ventilators necessary for the care of patients with severe infection, so that the risk of an overwhelming increase in deaths is latent (SÁNCHEZDUQUE et al, 2020).

The Pan American Health Organization works closely with central American and other continent countries to integrate COVID-19 into existing surveillance, based on surveillance of severe acute respiratory infections (hospitalized patients) and influenzalike diseases (outpatients), already in place as part of long-standing global influenza surveillance and more recently, for severe respiratory diseases since SARS and Influenza H1N1. This integration of approaches helps ensure long-term sustainable COVID-19 surveillance (ANDRUS et al., 2020).

As the SARS-CoV-2 pandemic progresses in Latin America, countries seek to acquire knowledge with other countries and implementing and following these methods is a challenge. As rich countries try new methods to maintain their economies, small island developing states face greater challenges. Islands belonging to the Dutch kingdom such as Curacao, St Martin and Aruba were quick to implement strict measures such as banning airspace and mitigation measures such as closing shops and restaurants. These measures, even though they were effective, caused great grief in the population because they generated the economic disaster because their economy depended on tourism and other sectors such as industry, which suffered from the lack of insum, causing $45 \%$ of the population to lose their jobs (some of these islands were already in economic recession), evidencing a worsening in an already weak economy (MARIA et al, 2020). 
medRxiv preprint doi: https://doi.org/10.1101/2020.12.26.20248872; this version posted January 2, 2021. The copyright holder for this preprint (which was not certified by peer review) is the author/funder, who has granted medRxiv a license to display the preprint in It is made available under a CC-BY-ND 4.0 International license .

In the Caribbean region, for example, natural disasters, little investment in health and frequent arbovirus epidemics have been a constant problem. The COVID-19 outbreak occurred in March in the Dominican Republic, then Cuba and Puerto Rico and also on islands such as St Martin and Barbados and in countries such as Haiti, where only a handful of people understand that coronavirus contagion occurs from person to person, regardless of their religion or ethnicity, and most believe that the virus is God's punishment, or that the elite manufactured the disease to annihilate minorities and the poorest, is the biggest of the problems encountered in virus mitigation (ESCOBEDO et al, 2020).

Latin America is marked by intense social inequality and with the arrival of SARS-CoV-2 this aspect was only more visible, demonstrating all the deficiency of the health system of these countries and its lack of infrastructure to deal with a pandemic. To correct these deficits, it is essential to rely on epidemiological surveillance, tracking new cases and establishing mandatory quarantine for those who come from outside, since according to all international organizations quarantine is the biggest step to reduce the rate (SÁNCHES-DUQUE, 2020).

Despite this, we at the Laboratory of Population Genetics and Computational Evolutionary Biology (LaBECom-UNIVISA) believe that contributing to geneticpopulation studies of SARS-CoV-2 in Central America can also be a valid strategy for virus mitigation, more precisely when we try to establish relationships and considerations about its molecular diversity. These considerations could help us in the support that, among other things, the more conserved the viral sequences found among all central American countries, the better the chances of resistance of the populations of these countries, since the genetic diversity of the entire Latin population may be reflected in the plasticity of clinical forms of COVID-19 found in these countries.

\section{Objective}

Test the levels of molecular diversity existing in complete Genomes of SARS-CoV-2 from Central America.

\section{Methodology}

Database: The 38 complete SARS-CoV-2 genomes, publicly available on the National Biotechnology Information Center (NCBI) platform of the five Central American countries (Belize, Guatemala, Cuba, Jamaica, and Puerto Rico), were rescued from 
medRxiv preprint doi: $h t t p s: / / d o i . o r g / 10.1101 / 2020.12 .26 .20248872$; this version posted January 2, 2021. The copyright holder for this preprint (which was not certified by peer review) is the author/funder, who has granted medRxiv a license to display the preprint in It is made available under a CC-BY-ND 4.0 International license .

\section{GENBANK}

(https://www.ncbi.nlm.nih.gov/labs/virus/vssi/\#/virus?SeqType_s=Nucleotide\&VirusLi neage_ss=Severe $\% 20$ acute $\% 20$ respiratory $\% 20$ syndrome $\% 20$ coronavirus $\% 202, \% 20$ taxi d:2697049\&Region_s=North\%20America) on October 20, 2020.

\section{For tree construction using FIGTREE V 1.4.4. (VLAD et al, 2008)}

To assemble the phylogenetic tree, we used the "Kimura 2-parameter" model with 100 pseudo-replications and as rates among sites we use the Gamma Distributed with Invariant Sites $(\mathrm{G}+\mathrm{I})$. The Newick tree, served as input for Figtree software.

\section{Genetic Structuring Analyses}

The Analysis of Molecular Variance (AMOVA), Genetic Distance, mismatch, demographic and spatial expansion analyses, molecular diversity and evolutionary divergence time were obtained with the Software Arlequin v. 3.5 (EXCOFFIER et al., 2005) using 1000 random permutations (NEI and KUMAR, 2000).

\section{All steps of this process are described in:}

https://dx.doi.org/10.17504/protocols.io.bmbvk2n6 (Félix et al., 2020).

\section{Results}

Of the 38 sequences analyzed, with sizes ranging from 29,570 to $29,882 \mathrm{bp}$, only 79 sites remained preserved, revealing a high degree of polymorphism for the whole set. The graphical representation of these sites can be seen in a logo built with weblogo 3 software. (CROOKS et al., 2004), where the size of each nucleotide is proportional to its frequency for specific sites. (Figure 1 and Table 1).

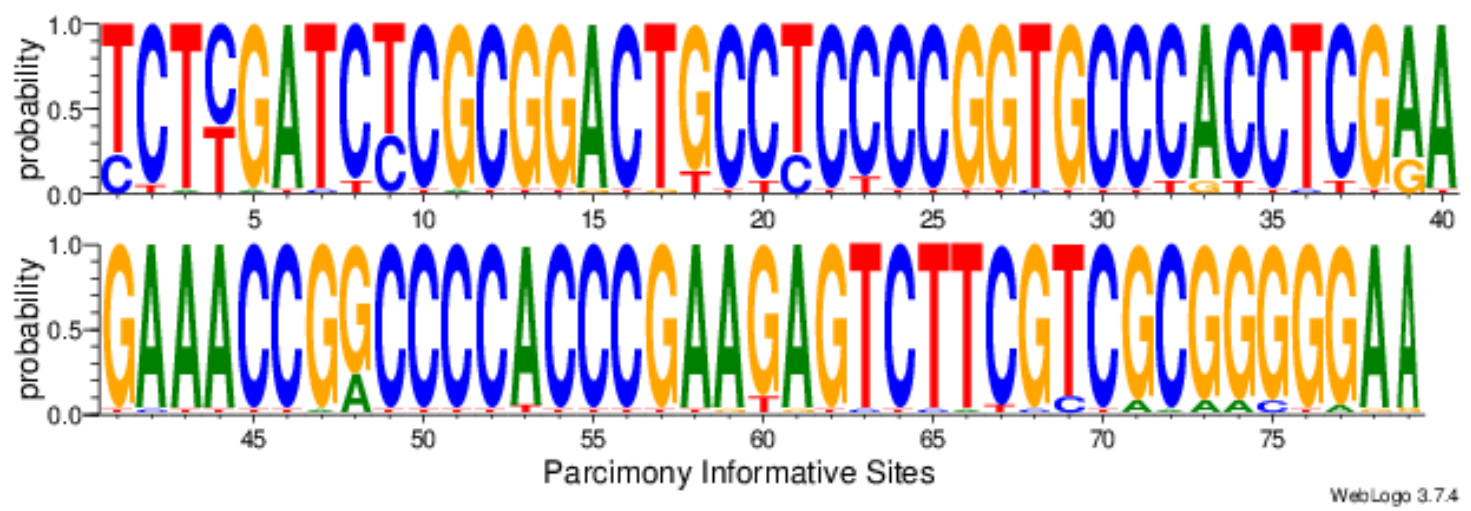

Figure 1: Graphic representation of 79 parsimonium-informative sites of complete Genomes of SARSCoV-2 from Central America. 
medRxiv preprint doi: https://doi.org/10.1101/2020.12.26.20248872; this version posted January 2, 2021. The copyright holder for this preprint (which was not certified by peer review) is the author/funder, who has granted medRxiv a license to display the preprint in It is made available under a CC-BY-ND 4.0 International license .

\section{Genetic Distance Analysis}

Genetic distance and molecular variance (AMOVA) analyses were significant for the groups studied. The $\mathrm{F}_{\mathrm{ST}}$ value (17\%) pointed out the existence of a considerable diversity among the countries studied, with significant evolutionary divergences within and between the groups studied. These analyses indicate the countries of Guatemala and Jamaica as the most genetically distant and the countries of Cuba and Puerto Rico as the most similar. (Figure 2 and Table 2).

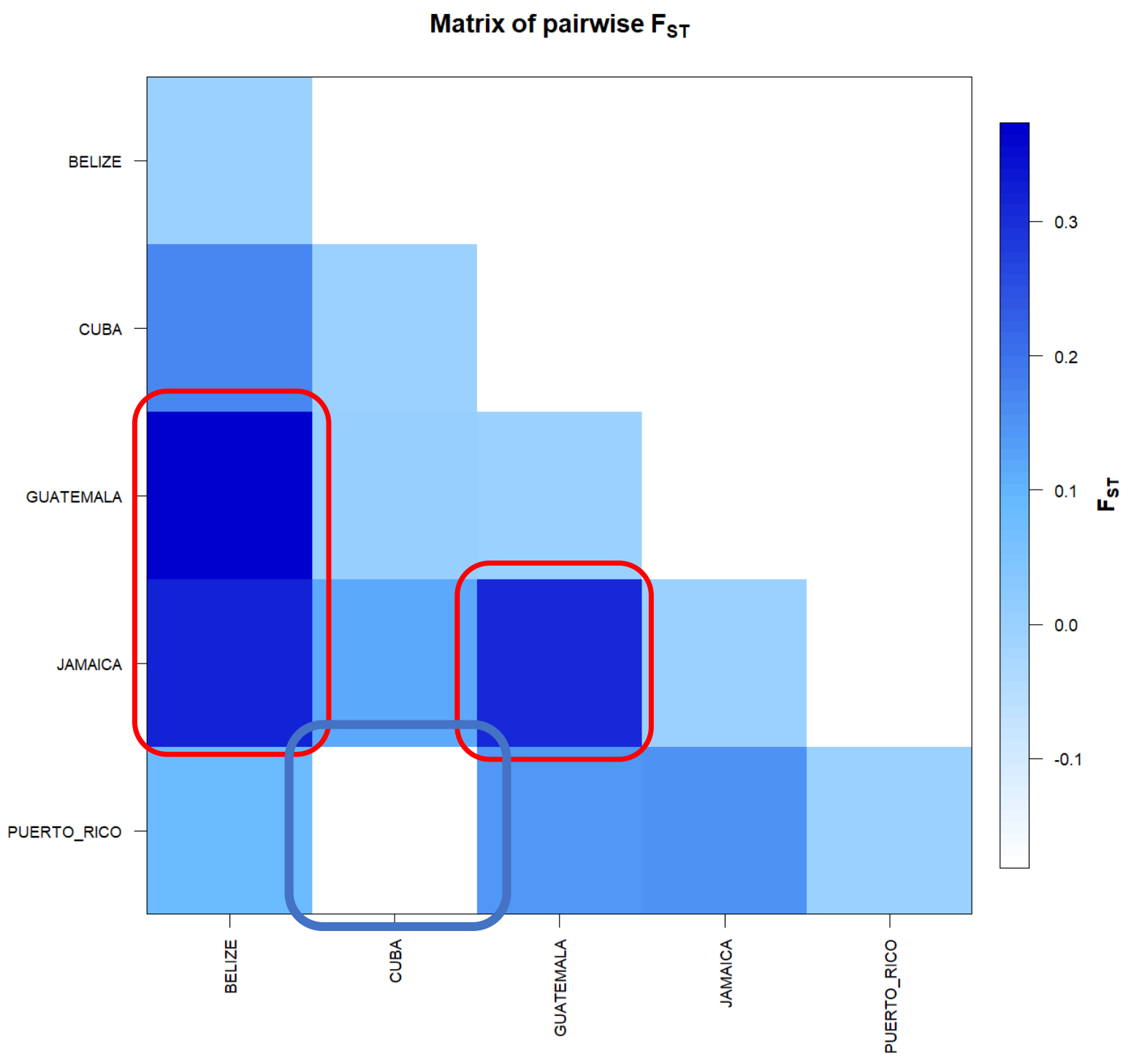

Figure 2. FST-based genetic distance matrix between for the 38 complete SARS-CoV-2 genomes from Central America. * Generated by the statistical package in $\mathrm{R}$ language using the output data of the Software Arlequin version 3.5.1.2. 


\begin{tabular}{|c|c|c|c|c|c|c|c|}
\hline Accession & Release Date & Specie & Length & Geo Location & Host & Isolation Source & Collection Date \\
\hline MT844023 & 05/08/2020 & $S A R S-C o V-2$ & 29882 & Belize & Homo sapiens & - & 20/03/2020 \\
\hline MT844024 & 05/08/2020 & $S A R S-C o V-2$ & 29882 & Belize & Homo sapiens & - & 01/03/2020 \\
\hline MT844026 & 05/08/2020 & $S A R S-C o V-2$ & 29873 & Belize & Homo sapiens & - & $27 / 03 / 2020$ \\
\hline MT844027 & 05/08/2020 & $S A R S-C o V-2$ & 29882 & Belize & Homo sapiens & - & 09/04/2020 \\
\hline MT873896 & $11 / 08 / 2020$ & $S A R S-C o V-2$ & 29811 & Cuba & Homo sapiens & - & $19 / 03 / 2020$ \\
\hline MT873897 & $11 / 08 / 2020$ & $S A R S-C o V-2$ & 29800 & Cuba & Homo sapiens & - & $24 / 03 / 2020$ \\
\hline MT844029 & 05/08/2020 & $S A R S-C o V-2$ & 29882 & Guatemala & Homo sapiens & oronasopharynx & $15 / 03 / 2020$ \\
\hline MT844031 & 05/08/2020 & $S A R S-C o V-2$ & 29882 & Guatemala & Homo sapiens & oronasopharynx & $15 / 03 / 2020$ \\
\hline MT844032 & 05/08/2020 & $S A R S-C o V-2$ & 29882 & Guatemala & Homo sapiens & oronasopharynx & $17 / 03 / 2020$ \\
\hline MT844033 & 05/08/2020 & SARS-CoV-2 & 29882 & Guatemala & Homo sapiens & oronasopharynx & $18 / 03 / 2020$ \\
\hline MT844034 & 05/08/2020 & $S A R S-C o V-2$ & 29882 & Guatemala & Homo sapiens & oronasopharynx & $19 / 03 / 2020$ \\
\hline MT844036 & 05/08/2020 & $S A R S-C o V-2$ & 29882 & Guatemala & Homo sapiens & oronasopharynx & 20/03/2020 \\
\hline MT844038 & 05/08/2020 & $S A R S-C o V-2$ & 29882 & Guatemala & Homo sapiens & oronasopharynx & 21/03/2020 \\
\hline
\end{tabular}




\begin{tabular}{|c|c|c|c|c|c|c|c|}
\hline MT844047 & $05 / 08 / 2020$ & $S A R S-C o V-2$ & 29882 & Guatemala & Homo sapiens & oronasopharynx & $13 / 03 / 2020$ \\
\hline MT844048 & $05 / 08 / 2020$ & $S A R S-C o V-2$ & 29882 & Guatemala & Homo sapiens & oronasopharynx & $15 / 03 / 2020$ \\
\hline МТ844049 & $05 / 08 / 2020$ & $S A R S-C o V-2$ & 29882 & Guatemala & Homo sapiens & oronasopharynx & $15 / 03 / 2020$ \\
\hline MT507271 & $22 / 05 / 2020$ & $S A R S-C o V-2$ & 29882 & Jamaica & Homo sapiens & swab & $09 / 03 / 2020$ \\
\hline MT507272 & $22 / 05 / 2020$ & $S A R S-C o V-2$ & 29882 & Jamaica & Homo sapiens & swab & $11 / 03 / 2020$ \\
\hline MT507273 & $22 / 05 / 2020$ & $S A R S-C o V-2$ & 29882 & Jamaica & Homo sapiens & swab & $14 / 03 / 2020$ \\
\hline MT507274 & $22 / 05 / 2020$ & $S A R S-C o V-2$ & 29882 & Jamaica & Homo sapiens & swab & $16 / 03 / 2020$ \\
\hline MT507275 & $22 / 05 / 2020$ & $S A R S-C o V-2$ & 29882 & Jamaica & Homo sapiens & swab & $16 / 03 / 2020$ \\
\hline MT507276 & $22 / 05 / 2020$ & $S A R S-C o V-2$ & 29882 & Jamaica & Homo sapiens & swab & $17 / 03 / 2020$ \\
\hline MT507793 & $22 / 05 / 2020$ & $S A R S-C o V-2$ & 29885 & Jamaica & Homo sapiens & swab & $11 / 03 / 2020$ \\
\hline MT507794 & $22 / 05 / 2020$ & SARS-CoV-2 & 29882 & Jamaica & Homo sapiens & swab & $16 / 03 / 2020$ \\
\hline MT419810 & $01 / 05 / 2020$ & $S A R S-C o V-2$ & 29758 & Puerto Rico & Homo sapiens & oronasopharynx & $23 / 03 / 2020$ \\
\hline MT419811 & $01 / 05 / 2020$ & SARS-CoV-2 & 29743 & Puerto Rico & Homo sapiens & oronasopharynx & $23 / 03 / 2020$ \\
\hline MT419812 & $01 / 05 / 2020$ & $S A R S-C o V-2$ & 29758 & Puerto Rico & Homo sapiens & oronasopharynx & $23 / 03 / 2020$ \\
\hline
\end{tabular}




\begin{tabular}{|c|c|c|c|c|c|c|c|}
\hline MT419813 & $01 / 05 / 2020$ & $S A R S-C o V-2$ & 29570 & Puerto Rico & Homo sapiens & oronasopharynx & $23 / 03 / 2020$ \\
\hline MT419814 & $01 / 05 / 2020$ & $S A R S-C o V-2$ & 29743 & Puerto Rico & Homo sapiens & oronasopharynx & $23 / 03 / 2020$ \\
\hline MT419815 & $01 / 05 / 2020$ & $S A R S-C o V-2$ & 29743 & Puerto Rico & Homo sapiens & oronasopharynx & $24 / 03 / 2020$ \\
\hline MT419816 & $01 / 05 / 2020$ & $S A R S-C o V-2$ & 29760 & Puerto Rico & Homo sapiens & oronasopharynx & $24 / 03 / 2020$ \\
\hline MT419817 & $01 / 05 / 2020$ & $S A R S-C o V-2$ & 29570 & Puerto Rico & Homo sapiens & oronasopharynx & $23 / 03 / 2020$ \\
\hline MT419818 & $01 / 05 / 2020$ & $S A R S-C o V-2$ & 29743 & Puerto Rico & Homo sapiens & oronasopharynx & $23 / 03 / 2020$ \\
\hline MT419819 & $01 / 05 / 2020$ & $S A R S-C o V-2$ & 29743 & Puerto Rico & Homo sapiens & oronasopharynx & $24 / 03 / 2020$ \\
\hline MT419820 & $01 / 05 / 2020$ & $S A R S-C o V-2$ & 29706 & Puerto Rico & Homo sapiens & oronasopharynx & $24 / 03 / 2020$ \\
\hline MT419821 & $01 / 05 / 2020$ & $S A R S-C o V-2$ & 29743 & Puerto Rico & Homo sapiens & oronasopharynx & $01 / 04 / 2020$ \\
\hline MT419822 & $01 / 05 / 2020$ & $S A R S-C o V-2$ & 29743 & Puerto Rico & Homo sapiens & oronasopharynx & $01 / 04 / 2020$ \\
\hline MW018448 & $18 / 09 / 2020$ & $S A R S-C o V-2$ & 29825 & Puerto Rico & Homo sapiens & oronasopharynx & 06/07/2020 \\
\hline
\end{tabular}

Source: NCBI Virus community portal

https://www.ncbi.nlm.nih.gov/labs/virus/vssi/\#/virus?SeqType_s=Nucleotide\&VirusLineage_ss=Severe\%20acute\%20respiratory\%20s yndrome\%20coronavirus\%202,\%20taxid:2697049\&Region_s=North\%20America 
medRxiv preprint doi: https://doi.org/10.1101/2020.12.26.20248872; this version posted January 2, 2021. The copyright holder for this preprint (which was not certified by peer review) is the author/funder, who has granted medRxiv a license to display the preprint in It is made available under a CC-BY-ND 4.0 International license.

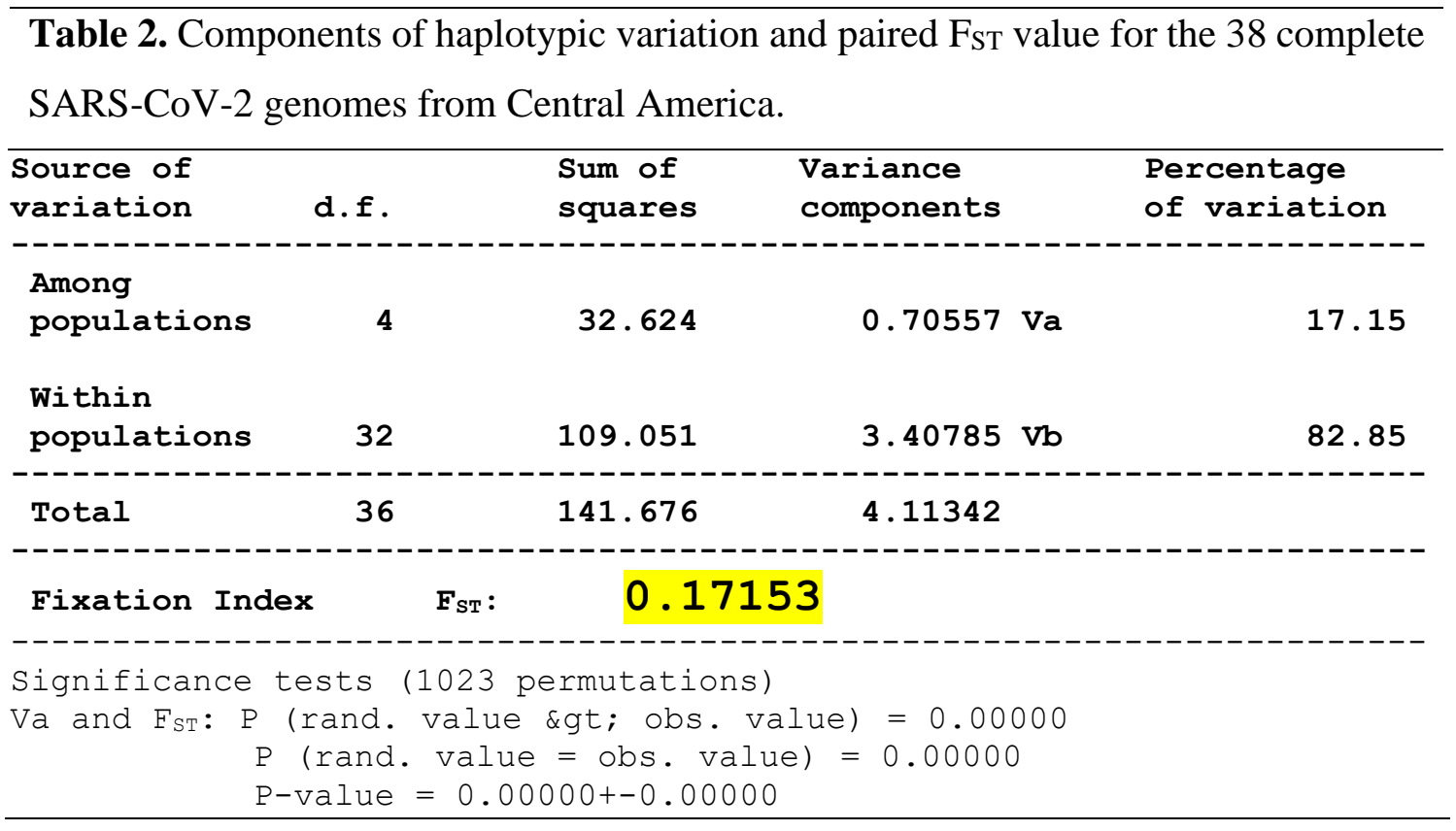

The analyses confirmed the presence of high and statistically significant variations, evidencing a high genetic dissimilarity among all haplotypes. However, the use of the divergence matrix, in the construction of the tree helped in the recognition of minimal similarities between some haplotypes, including at different geographical points. The maximum divergence patterns were also obtained when less robust methods of phylogenetic pairing (e.g. UPGMA) were used, reflecting the non-haplotypic structure in the clades. With the use of the divergence matrix, it was possible to identify geographical variants that had less genetic distance and the "a posteriori" probabilities were able to separate the main clusters into additional small groups, confirming the presence of a minimum probability of kinship between haplotypes (Figure 3).

The Tau variations, related to the ancestry of some groups, revealed a significant time of divergence, supported by mismatch analysis and demographic and spatial expansion analyses (Table 3).

Molecular diversity analyses estimated by $\varphi$ reflected a significant level of mutations among all haplotypes (transitions and transversions). The "indels" mutations (insertions or additions) were not found in any of the five groups studied. The Tajima and Fs de Fu tests showed disagreements between the estimates of general $\varphi$ and $\pi$, but with negative and highly significant values, indicating, once again, the absence of population expansions. The irregularity index ( $\mathrm{R}=$ Raggedness) with parametric bootstrap, simulated 
medRxiv preprint doi: https://doi.org/10.1101/2020.12.26.20248872; this version posted January 2, 2021. The copyright holder for this preprint (which was not certified by peer review) is the author/funder, who has granted medRxiv a license to display the preprint in

perpetuity.
It is made available under a CC-BY-ND 4.0 International license .

new values $\varphi$ for before and after a supposed demographic expansion and, in this case, assumed a value equal to zero for all groups (Table 4); (Figure 4).

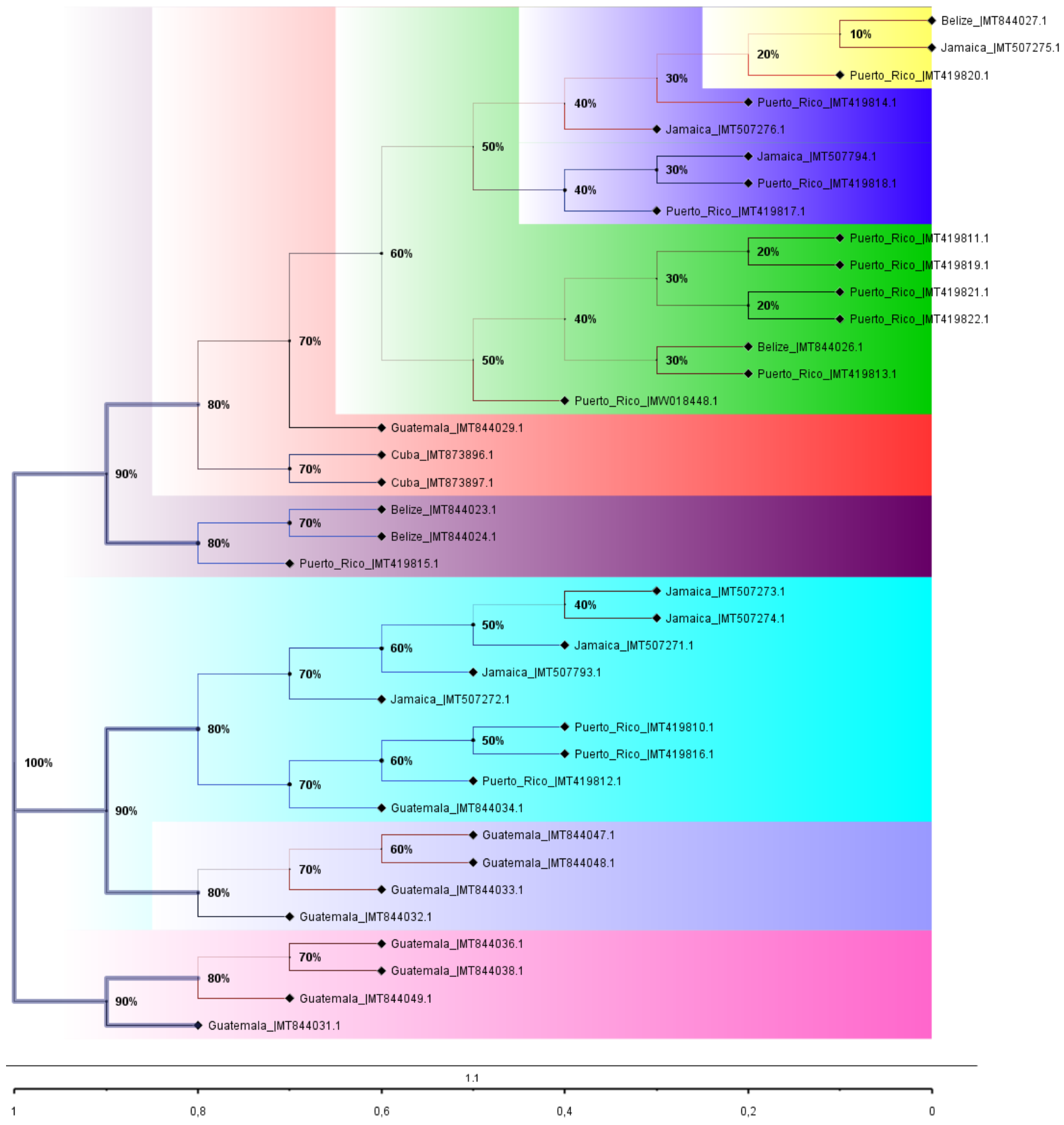

Figure 3. Phylogenetic Tree of the 38 complete Genomes of SARS-CoV-2 from Central America. We assume the need to display the "a posteriori" probabilities for each of the clades present, as well as the estimation of the age of each node. A reverse temporal scale was constructed to understand the evolutionary history of the set. We chose to draw the tree with thick lines and the clades were colored by selecting the branches. Finally, we export the tree in NEXUS and generate graphics files in PNG. * Tree built using FIGTREE V 1.4.4. (VLAD et al, 2008). 
Table 3. Demographic and spatial expansion simulations based on the $\tau, \theta$, and M indices of sequences of the 38 complete Genomes of SARSCoV-2 from Central America.

$\begin{array}{lllll}\text { Statistics } & \text { BELIZE } & \text { CUBA } & \text { GUATEMALA SAMAICA PUERTO RICO MEAN }\end{array}$

\section{Demographic expansion}

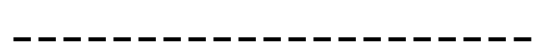

$\begin{array}{rrrrrrrr}\text { Tau } & 8.00000 & 0.00000 & 1.50000 & 12.37307 & 3.00000 & 4.97461 & 5.11393 \\ \text { Theta0 } & 0.66250 & 0.00000 & 0.00000 & 0.00000 & 7.19998 & 1.57250 & 3.15891 \\ \text { Thetal } & 3417.48520 & 0.00000 & 6829.37028 & 23.76217 & 6934.95629 & 3441.11479 & 3435.37960 \\ \text { SSD } & 0.42852 & 0.00000 & 0.04638 & 0.11977 & 0.01868 & 0.12267 & 0.17694 \\ \text { Raggedness index } & 1.00000 & 0.00000 & 0.15457 & 0.37628 & 0.04033 & 0.31424 & 0.41030\end{array}$

\section{Spatial expansion}

$\begin{array}{rrrrrrrr}\text { Tau } & 8.74785 & 0.00000 & 1.65237 & 12.03616 & 3.38650 & 5.16457 & 5.05541 \\ \text { Theta } & 0.00072 & 0.00000 & 0.01000 & 0.00072 & 7.78697 & 1.55968 & 3.48116 \\ M & 2.58419 & 0.00000 & 4397.92467 & 8.91409 & 4379.13801 & 1757.71219 & 2401.60969 \\ \text { SSD } & 0.34339 & 0.00000 & 0.04774 & 0.12062 & 0.01843 & 0.10603 & 0.14042 \\ \text { Raggedness index } & 1.00000 & 0.00000 & 0.15457 & 0.37628 & 0.04033 & 0.31424 & 0.41030\end{array}$




\begin{tabular}{|c|c|c|c|c|c|c|c|}
\hline Statistics & BELIZE & CUBA & GUATEMALA & JAMAICA & PUERTO RICO & Mean & s.d. \\
\hline No. of transitions & 6 & 0 & 13 & 16 & 30 & 13.000 & 11.358 \\
\hline No. of transversions & 2 & 0 & 3 & 3 & 17 & 5.000 & 6.819 \\
\hline No. of substitutions & 8 & 0 & 16 & 19 & 47 & 18.000 & 17.819 \\
\hline No. of indels & 0 & 0 & 0 & 0 & 0 & 0.000 & 0.000 \\
\hline No. of ts. sites & 6 & 0 & 13 & 16 & 30 & 13.000 & 11.358 \\
\hline No. of tv. sites & 2 & 0 & 3 & 3 & 17 & 5.000 & 6.819 \\
\hline $\begin{array}{r}\text { No. of subst. sites } \\
\text { Total: } 73\end{array}$ & 8 & 0 & 16 & 19 & 47 & 18.000 & 17.819 \\
\hline No. private subst. sites & 4 & 0 & 11 & 11 & 35 & 12.200 & 13.590 \\
\hline No. of indel sites & 0 & 0 & 0 & 0 & 0 & 0.000 & 0.000 \\
\hline $\mathrm{Pi}$ & 5.333 & 0.000 & 3.711 & 7.679 & 9.253 & 5.19515 & 3.60009 \\
\hline Theta_k & N.A. & N.A. & N.A. & N.A. & N.A. & N.A. & N.A. \\
\hline Theta_k_lower & N.A. & N.A. & N.A. & N.A. & N.A. & N.A. & N.A. \\
\hline Theta_k_upper & N.A. & N.A. & N.A. & N.A. & N.A. & N.A. & N.A. \\
\hline Theta_H & N.A. & N.A. & N.A. & N.A. & N.A. & N.A. & N.A. \\
\hline s.d. Theta_H & N.A. & N.A. & N.A. & N.A. & N.A. & N.A. & N.A. \\
\hline Theta_S & 5.33333 & 0.00000 & 5.65577 & 7.32782 & 14.77925 & 6.61924 & 5.32644 \\
\hline s.d. Theta_S & 3.52767 & 0.00000 & 2.61495 & 3.48790 & 5.77834 & 3.08177 & 2.08270 \\
\hline Theta_pi & 5.33333 & 0.00000 & 3.71111 & 7.67857 & 9.25275 & 5.19515 & 3.60009 \\
\hline s.d. Theta pi & 4.39978 & 0.00000 & 2.31400 & 4.56493 & 5.08178 & 3.27210 & 2.11202 \\
\hline
\end{tabular}


medRxiv preprint doi: https://doi.org/10.1101/2020.12.26.20248872; this version posted January 2, 2021. The copyright holder for this preprint (which was not certified by peer review) is the author/funder, who has granted medRxiv a license to display the preprint in It is made available under a CC-BY-ND 4.0 International license .

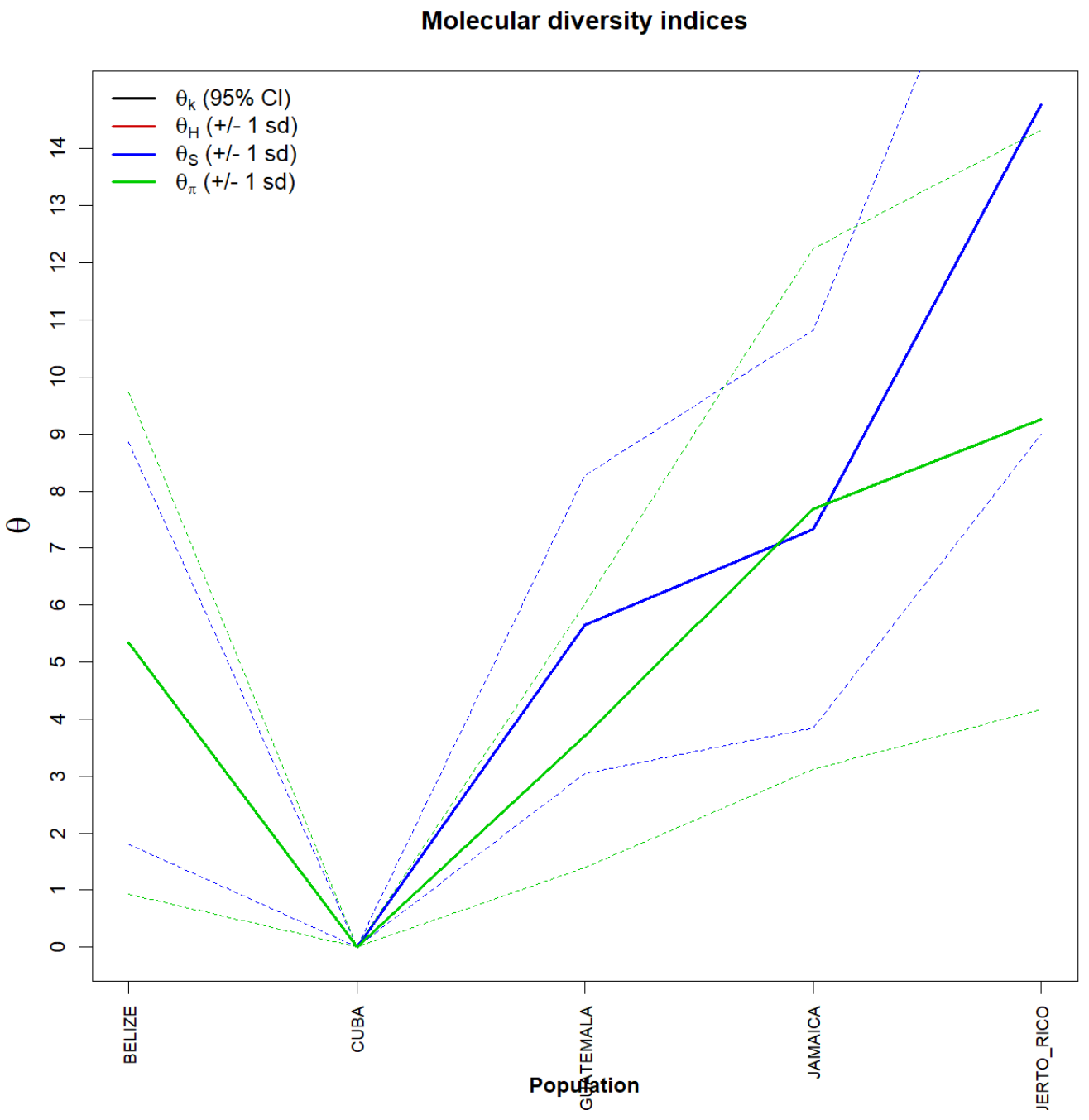

Figure 4. Graph of molecular diversity indices of the 38 complete Genomes of SARS-CoV-2 from Central America. In the graph the values of $\theta:(\theta \mathrm{k})$ Relationship between the expected number of alllos $(\mathrm{k})$ and the sample size; $(\theta \mathrm{H})$ Expected homozygosity in a balanced relationship between drift and mutation; $(\theta \mathrm{S})$ Relationship between the number of segregating sites (S), sample size (n) and non-recombinant sites; $(\theta \pi)$ Relationship between the average number of paired differences $(\pi)$ and $\theta$. * Generated by the statistical package in $\mathrm{R}$ language using the output data of the Arlequin software version 3.5.1.2.

\section{Discussion}

With the use of analysis methodologies employed, it was possible to detect the existence of a small degree of similarity between the SARS-CoV-2 haplotypes of Central America. As no significant levels of structuring were found, we assumed that there were high levels of variation probably related to a gain of intermediate haplotypes over time, associated, perhaps, with a significant increase in genetic flow. The occurrence of 
medRxiv preprint doi: https://doi.org/10.1101/2020.12.26.20248872; this version posted January 2, 2021. The copyright holder for this preprint (which was not certified by peer review) is the author/funder, who has granted medRxiv a license to display the preprint in It is made available under a CC-BY-ND 4.0 International license .

geographical Isolation from past fragmentation events may have generated a continuous pattern of genetic divergence between the groups, since the high values found for genetic distance support the presence of a pattern of continuous divergence between haplotypes, as well as in the frequency of polymorphisms. This suggests that molecular diversity may be due to synonymous substitutions as the main components of variations. All analyses confirm that there is no consensus on the conservation of the SARS-CoV-2 genome in Central America, contrary to what was described by FELIX et al, 2020, for some countries in South America, and it is safe to state that the genetic variability of the Virus is different for subsets of countries throughout the American continent.

These considerations were also supported by simple phylogenetic pairing methodologies, such as UPGMA, which in this case, with a discontinuous pattern of genetic divergence between groups, showed a large number of branches with many mutational stages. These mutations possibly settled to drift due to the founder's effect, which accompanies the dispersive behavior and/or loss of intermediate haplotypes throughout the generations. The values found for the genetic distance considered the minimum differences between the groups, as well as the inference of values greater than or equal to those observed in the proportion of these permutations, including the $\mathrm{p}$-value of the test.

The discrimination of the five genetic entities was also perceived when the interhaplotypic variations were hierarchised in all components of covariance: by their intra- and inter-individual differences or by their intra- and intergroup differences, generating dendrograms that supported the idea that the significant differences found in the group of Guatemala, Jamaica and Puerto Rico, for example, can even be shared in their number, but not in their form, since the result of estimates of the average evolutionary divergence within the groups was low.

Since no relationship was made between genetic distance and geographic distance (mantel test) in this study, we assumed that the absence of genetic flow (observed by nonhaplotypic sharing) between the studied regions is due to the presence of natural geographic barriers. The $\varphi$ estimators, although extremely sensitive to any form of molecular variation, supported the uniformity between the results found by all the methodologies employed, and can be interpreted as a confirmation that there is no consensus in the conservation of sequences among the Central American countries studied, and it is safe to state that the large number of polymorphisms found should be 
medRxiv preprint doi: $h t t p s: / / d o i . o r g / 10.1101 / 2020.12 .26 .20248872$; this version posted January 2, 2021. The copyright holder for this preprint (which was not certified by peer review) is the author/funder, who has granted medRxiv a license to display the preprint in It is made available under a CC-BY-ND 4.0 International license .

directly reflected in a high variation for protein products of the virus, a fact that draws attention to the maintenance and increase of all public health actions employed.

\section{References}

Andrus JK, Evans-Gilbert T, Santos JI, et al. Perspectives on Battling COVID-19 in Countries of Latin America and the Caribbean. Am J Trop Med Hyg. 2020;103(2):593-596. doi:10.4269/ajtmh.20-0571.

Bautista-Molano W, Ferreyra Garrot L, Toro C; PANLAR Joven. Exploring the Impact of COVID-19 in Latin America. J Clin Rheumatol. 2020.

Callejas D, Echevarría JM, Carrero Y, Rodríguez-Morales AJ, Moreira R. The SARSCoV-2 Pandemic in Latin America: The Need for Multidisciplinary Approaches. Curr Trop Med Rep. 2020 Nov 3:1-6. doi: 10.1007/s40475-020-00219-w. Epub ahead of print. PMID: 33169096; PMCID: PMC7609365.

Escobedo A A, Rodríguez-morales A J, Almirall, P, Almanza C, Rumbault R. SARSCoV-2/COVID-19: Evolution in the Caribbean islands. Travel Medicine and Infectious Disease, v. 37, p. 101854, 2020. Disponível em: <https://www.ncbi.nlm.nih.gov/pmc/articles/PMC7450220/>. Acesso em: 19 Dec. 2020. Felix, P.T; Nascimento Filho, C.B.; Ramos, R.S.; Paulino, A.J.; Venâncio, D.B.R.. Levels of genetic diversity of SARS-CoV-2 virus: reducing speculations about the genetic variability of the virus in South America. bioRxiv 2020.09.14.296491; doi: https://doi.org/10.1101/2020.09.14.296491.

Henriquez-Marquez KI, Zambrano LI, Arteaga-Livias K, Rodríguez-Morales AJ. Prevención e identificación temprana de casos sospechosos COVID-19 en el primer nivel de atención en Centro América [Prevention and early identification of COVID19 suspected cases at the first level of care in Central America. Aten Primaria. 2020.

Maria P, Jeung L, Duits A, Busari J. SARS-CoV-2 outbreak on the Caribbean islands of the Dutch Kingdom: a unique challenge. Revista Panamericana de Salud Pública, v. 44, $\quad$ p. $\quad 1, \quad 2020 . \quad$ Disponível em: <https://www.ncbi.nlm.nih.gov/pmc/articles/PMC7429931/>. Acesso em: 19 Dec. 2020. 
medRxiv preprint doi: $h t t p s: / / d o i . o r g / 10.1101 / 2020.12 .26 .20248872$; this version posted January 2, 2021. The copyright holder for this preprint (which was not certified by peer review) is the author/funder, who has granted medRxiv a license to display the preprint in It is made available under a CC-BY-ND 4.0 International license.

Murphy MM, Jeyaseelan SM, Howitt C, et al. COVID-19 containment in the Caribbean: The experience of small island developing states. Research in Globalization. 2020;2:100019. doi:10.1016/j.resglo.2020.100019.

Pierre Teodosio Felix, Robson da Silva Ramos, Dallynne Bárbara Ramos Venâncio, Cícero Batista do Nascimento Filho, Antônio João Paulino 2020. Mathematical models for understanding the genetic diversity of the new coronavirus: LaBECom's analytical protocols. protocols.iohttps://dx.doi.org/10.17504/protocols.io.bmbvk2n6.

Rodriguez-Morales AJ, Gallego V, Escalera-Antezana JP, et al. COVID-19 in Latin America: The implications of the first confirmed case in Brazil. Travel Med Infect Dis. 2020;35:101613. doi:10.1016/j.tmaid.2020.101613

Sánchez-Duque JA, Arce-Villalobos LR, Rodríguez-Morales AJ. Enfermedad por coronavirus 2019 (COVID-19) en América Latina: papel de la atención primaria en la preparación y respuesta [Coronavirus disease 2019 (COVID-19) in Latin America: Role of primary care in preparedness and response]. Aten Primaria. 2020.

Tamura K. Estimation of the number of nucleotide substitutions when there are strong transition-transversion and $\mathbf{G}+\mathbf{C}$-content biases. Molecular Biology and Evolution 9:678-687. (1992).

Vlad I. Morariu, Balaji Vasan Srinivasan, Vikas C. Raykar, Ramani Duraiswami, and Larry S. Davis. Automatic online tuning for fast Gaussian summation. Advances in Neural Information Processing Systems (NIPS), 2008.

Yuan, J, Wu Y, Jing W, Liu J, Du M, Wang Y, Liu M. Non-linear correlation between daily new cases of COVID-19 and meteorological factors in 127 countries. Environmental Research, v. 193, p. 110521, 2021. Disponível em: <https://www.ncbi.nlm.nih.gov/pmc/articles/PMC7713195/>. Acesso em: 19 Dec. 2020. 